\title{
Principles of Design for Sustainable Group Housing Projects in India
}

\author{
Gaurav Gangwar ${ }^{1,2, *}$, Prabhjot Kaur ${ }^{3}$, Inderpal Singh ${ }^{4}$ \\ ${ }^{1}$ Research Fellow, Faculty of Planning and Architecture, IKG Punjab Technical University Jalandhar, Punjab, India \\ ${ }^{2}$ Associate Professor, Chandigarh College of Architecture, Chandigarh Administration, Chandigarh (U.T.), India \\ ${ }^{3}$ Director, School of Built Environment, IKG PTU Mohali Campus II, Sector 115 Mohali, Punjab, India \\ ${ }^{4}$ Associate Professor, \& Head, Department of Architecture, National Institute of Technology, Hamirpur, HP, India
}

Received September 25, 2020; Revised November 6, 2020; Accepted November 29, 2020

\begin{abstract}
Cite This Paper in the following Citation Styles
(a): [1] Gaurav Gangwar, Prabhjot Kaur, Inderpal Singh, "Principles of Design for Sustainable Group Housing Projects in India," Civil Engineering and Architecture, Vol. 8, No. 6, pp. 1234 - 1250, 2020. DOI: 10.13189/cea.2020.080608.
\end{abstract}

(b): Gaurav Gangwar, Prabhjot Kaur, Inderpal Singh (2020). Principles of Design for Sustainable Group Housing Projects in India. Civil Engineering and Architecture, 8(6), 1234 - 1250. DOI: 10.13189/cea.2020.080608.

Copyright $\bigcirc 2020$ by authors, all rights reserved. Authors agree that this article remains permanently open access under the terms of the Creative Commons Attribution License 4.0 International License

\begin{abstract}
There are three rating systems available to assess the sustainability of Group Housing in India provided by three agencies, namely the Indian Green Building Council (IGBC), Green Rating for Integrated Habitat Assessment (GRIHA), and Eco Housing Assessment Criteria's. The parameters for all three rating systems have some differentials. The building rated under one rating system may not obtain a rating under another rating system. It means that designers' attention is restricted to the rating system's criteria and has lost the sustainable design process's true spirit. This paper aims to establish the Principles of Design that meet all the rating system's maximum criteria. The methodology followed for this paper includes a brief review of all rating systems and a comparative analysis of similarity and dissimilarity to understand the key focus areas of all three rating systems. The Principles of Design are applied to fulfill all the three-rating system requirements with each focus area. The applications of design principles in the project indicate that only a certain number of Principles of Design are applied to achieve the rating system in each project, and many Principles of Design are overlooked. This was due to the designer's approach to sustainable buildings as a product based on the rating system. The Principles of Design generated in this paper will be a ready source of guidance for India's sustainable housing design. The designer should initially approach sustainable design as a design process and, later on, achieve a sustainable design for a specific rating system.
\end{abstract}

Keywords IGBC, Sustainable Housing, GRIHA, Rating System, Eco housing Assessment

\section{Introduction}

India's population has multiplied over the last few decades. There is a shortage of facilities in India at all levels; India's lack of accommodation is a significant problem. This housing shortage is more critical in urban centers due to rapid urban growth of 2.8 percent over 2001-2011, resulting in a rise in urbanization from 27.8 percent to 31.2 percent. Out of the 1.2 billion Indian population, the urban population is 377 million. The report submitted by the technical committee of the Ministry of Housing and Urban Poverty Alleviation (MHUPA) in 2012 estimated almost 18.78 million household shortages in India. [1]

Rapid urbanization has put too much pressure on the city's finite resources. It has led to a shortage of essential services like potable water, sewage network, sanitation facility, electricity roads, waste disposal, and many more. Rapid urbanization has led to the destruction of green covers and water bodies. [2] The housing sector has a large share of rapid urbanization.

It is not possible to control the rapid urbanization. The only choice left to minimize the worst impact of rapid urbanization through sustainability. Sustainable Housing 
has an excellent opportunity to foster economic growth, environmental stewardship, quality of life, and social equity. [3] Sustainable housing would also reduce urban slums, harmful effects on climate change, and natural resources.

\subsection{Aim}

To generate principles of design of sustainable housing in India based on the rating system and understand the application of these principles of design in creating sustainable housing.

\subsection{Objectives}

a) To study the different concepts of sustainable development, the domains of sustainable development, the general principles of sustainable design.

b) To study an overview of India's rating system for housing projects such as LEED, GRIHA, and Eco-Housing Assessment Criteria.

c) To generate principles of design of sustainable housing in India based on a rating system.

d) To understand the application of these principles of design in creating sustainable housing.

\subsection{Significance of the Study}

1. This study will provide the design principles for sustainable housing to meet all three rating systems' criteria.

2. This study will provide a concise form of sustainable design principles for architects, architectural students, owners, builders for ready reference rather than comprehensive and complicated rating systems.

3. The design principles for sustainable housing are not available in a standard format and are described by various authors based on their experience and expertise. The design principle based on the rating system of this paper will be treated as a standard format.

\subsection{Scope and Limitation}

This research is limited to a multi-story group housing project with low-rise and mid-rise apartments and does not cover high-rise housing projects. The principles of design for sustainable housing only overview and further in-depth study is required of these design principles by other researchers. This study deals only with the environmental domain of sustainability.

\section{Literature Review}

\subsection{Sustainable Rating System of Housing in India: An Overview}

It is essential to understand the basic definitions of sustainable development, the domain of sustainable development, and the principles of sustainable design to understand India's sustainable rating system, especially in the context of sustainable housing principles of design.

\subsubsection{Definitions of Sustainable Development}

Sustainable Development is a vast domain. There are various definitions available for sustainable development, which are described below:

a). Defined as "the continued ability of a society, an ecosystem, or any such interactive system of function without exhausting key resources and without adversely affecting the environment."

b). "Development that meets the needs of the present without compromising the ability of future generations to meet their own need"- from the World Commission on Environment and Development's (the Brundtland Commission) report Our Common Future (Oxford: Oxford University Press, 1987). [11]

c). "Sustainable development, sustainable growth, and sustainable use have been used interchangeably as if their meanings were the same. They are not. Sustainable growth is a contradiction in terms: nothing physical can grow indefinitely. Sustainable use is only applicable to renewable resources. Sustainable development is used in this strategy to mean: improving the quality of human life whilst living within the carrying capacity of the ecosystems."- IUCN, UNEP, WWF (1991) [4]

d). "Most societies want to achieve economic development to secure higher standards of living, now and for future generations. They also seek to protect and enhance their environment, now and for their children. Sustainable development tries to reconcile these two objectives."- HMSO (1994) [11]

\subsubsection{Domains of Sustainable Development}

Sustainable Development or Sustainability has three domains: the environment, the economy, and society. Few authors have further extended this; it is reconfigured as four social-ecology, economics, politics, and culture domains. [12]

\subsubsection{Overview of Principles of Sustainable Design}

The term "Sustainable design "is an extensive discipline that encompasses various fields, including product design, architectural design, interior design, graphic design, and many more. Sustainable design is a design process that can integrate an environmentally friendly approach and consider natural resources as part of the design process. $\mathrm{Mr}$. Smith Lewis defines sustainable design in the architectural sector as follows: "Sustainable design is the practice of designing buildings in such a way that they function in harmony with natural systems." [13]

According to Jason F. McLennan, "The Philosophy of Sustainable Design," 2004, there are six principles of 
sustainable design, as listed below: [14]

i. Learning from natural systems (Biomimicry Principle)

ii. Respect for energy \& natural resources (Conservation Principle)

iii. Respect for people (Human Vitality Principle)

iv. Respect for a place (Ecosystem Principle),

v. Respect for future ("Seven Generations" Principle)

vi. Systems thinking (Holistic Principle)

\subsection{Need and Relevance of the Study}

Saigaonkar, RishabhG., Pimplikar S. S., Aher Pritesh D., in their research paper titled "Unique Green Building Rating System: Comparing Various Existing Rating Systems, "explores and compares different rating systems and has built a unique rating system to satisfy all the criteria of all rating systems. The study concludes that the unique rating system developed has the benefit of each system while overcoming the individual rating systems disadvantages. [4]

Virendra Kanaujia, Arukala Suchith Reddy, and G Kalyan Kumar, in their research paper titled "Comparative Review of Indian Green Building Rating Systems," discussed a comparative study of IGBC and GRIHA on the parameters of certification cost, influence and popularity, performance criteria, and benchmarking (rating score). The study concludes that IGBC has applied the International Standards and that the GRIHA rating has carried out under Indian conditions. [5]

Yashwanth Pamu and Kona Mahesh, in their research paper titled "A Comparative Study on Green Building Rating Systems in India in terms of Energy and Water," discussed on energy and water criteria's of two rating system, IGBC, and GRIHA. The study concludes that there are different parameters in both rating systems for energy and water and that it is difficult for stakeholders to select the rating system. It is safer to have one rating system in India. [6]

Kiran Joseph, Victor Jose, Dinesh Kumar A N, and Sithara Mary Sunny, in their research paper titled "A Review on various Green Building Rating Systems in India," discussed evaluation methods; scopes, and performance criteria and energy rating measures of IGBC and GRIHA. The study concludes that each system has strong points and weak points and does not seem to be too specific to certain assessment criteria. [7]

Laxman Jadhav, Shivani Lokhande, Apurva Bade, Anant Tupe, and Arun Sankpal, in their research paper titled "Comparative Study of LEED, BREEAM and GRIHA Rating System," discussed the similarity, differences, strength, and weakness of LEED, BREEAM, and GRIHA. They have also discussed whether these rating systems can assess the full sustainability of the project. The study concludes that a new unique rating system, combining all three rating systems, is recommended. [8]
H.P. Thanu and Dr. C. Rajasekaran, in their research paper titled "Comparative study on Indian building assessment tools and its limitations," discussed assessment approaches of different rating system for environmental, economic, and social aspects of sustainability. The study concludes that there is a considerable gap between sustainable building assessment tools at the regional level, and the implementation of international tools in India would have shortcomings. They also conclude that these rating systems are useful for streamlining the process but do not reliably calculate the environmental effect of Building Energy. [9]

Iliyas Ikbal Sande and N. S. Phadtare, in their research paper titled "Comparative Study of LEED and GRIHA Rating System," disused assessment methods; scopes, and performance criteria, and energy rating scales of LEED and GRIHA rating system. The study concludes that both rating systems have different parameters, so there is a possibility that the same building rated differently. The rating systems are complicated and do not offer a clear picture of project sustainability effectiveness, often confusing the architects and builders. The study recommends a simple and straightforward agenda for small contractors to understand and implement the project's rating system. [10]

Thus, to conclude, the rating systems do not have similar criteria and do not guarantee the implementation of all sustainable design points. These are very complex and difficult for stakeholders to understand. Their effectiveness in the Indian context, particularly with so much regional variation, is highly questionable. There is a need to develop a single rating system that completely blends all aspects of sustainability.

The literature review may also conclude that no study has addressed design principles based on comparing rating systems to include all parameters. There is still no specific study available for housing-specific rating systems. This study will be unique to address all the criteria of three rating systems in one, and also, this study will be first to discuss the rating system specific to Housing.

\section{Methodology}

The primary purpose of the methodology is to fulfill the aim and objectives of the research problem. The rating system does not cover the entire spectrum of sustainability, so there is a need to establish sustainability and sustainable design vision in the Indian context through literature review. The literature review helps to discuss the different concepts of sustainable development that ultimately help recognize sustainability in a broader sense. The definitions of sustainability discussed in the paper are not provided by individuals but are defined by different commissions at the international level. The different domains of sustainability and sustainable design 
principles have been discussed in this paper through the literature review.

The various broachers and manuals available for housing rating agencies, such as IGBC, GRIHA, and Eco Housing Assessment Criteria, are used to study the various sustainable rating systems. The rating agency divides the entire manual into different parts, and further, these sections are divide into different criteria, and the points are allocated to each criterion. It is essential to study the priority of the different sections available in the rating system. The rating system is studied based on the different significant sections divided by the rating agencies, the number of criteria and points available in each section, and the weighting of the percentage of those sections. The certification process was also addressed quite briefly.

All rating systems have similarities and differentials in different sections, their weighting. The comparative analysis is essential for understanding similarity and dissimilarity and to list all the areas of focus of the different ratings, the weighting provided by each rating system in these areas of focus. For further study of the detailed rating system, focused areas are defined.

The rating systems treat design as a product, and Principles of Design treat design as a design process. Therefore the conversion of the criteria of the rating system into Principles of design is essential. All rating systems are compared under focused area site planning, energy consumption and daylighting, sustainable building materials, water conservation, and waste management. All other focused areas will be put in under the Miscellaneous head Categories. The Principals of design have been worked out to address all criteria under each rating system.

The case studies are performed to understand the applicability of Principals of Design in Housing projects. All case studies selected are small-site projects of not more than 5 acres, low-rise, and medium-rise housing projects. In the one case study $\mathrm{T}$ Zed homes, selected for IGBC ranking, the author had visited the site personally and interacted with users. The other two case studies are the latest GRIHA's rated housing project and are carried out through a literature review. Case studies are explored in all focused areas, as discussed in the Principles of Design, such as site planning, energy and daylight use, sustainable building materials, water conservation, and waste management.

\section{Analysis and Discussion}

The analysis and discussion are divided into three parts; the first part consists of defining the focus area of the study using a comparative analysis of the rating system; the second part consists of drawing up the concepts of sustainable housing design through means of a detailed comparative analysis of the rating system in a targeted area. The third part consists of studying the applications of these derived principles of design in sustainable housing projects.

\subsection{Analysis of Sustainable Rating Systems for Housing in India}

There are agencies such as the Indian Green Building Council (IGBC), the Green Rating for Integrated Habitat Assessment (GRIHA), the Eco Housing Assessment Criteria, which evaluate sustainable designs for different parameters and offer various building certifications, as shown in Table 2, Table 4 and Table 6 . They are called the rating system, and these agencies are called rating agencies. These evaluation systems remain silent on the design process and are more interested in the product; of course, many design processes have recently been integrated into the GRIHA rating system. However, it is not easy to identify sustainable design principles through the rating system, so there is a need to establish design principles to fulfill all the rating system specifications.

\subsubsection{IGBC Rating System for Housing}

Indian Green Building Council (IGBC) has launched the rating system, the name of "IGBC Green Residential Societies recently." IGBC Green Residential Societies rating system consists of six sections, namely Green Facilities, Operation and Maintenance, Water Management, Energy Conservation, Waste Management, Resident Health \& Wellbeing, Exceptional Green Practices as shown in Table 1. [15]

Table 1. Criteria's, Points, and Weightage

\begin{tabular}{|c|c|c|c|}
\hline Sections & Criteria's & Points & Weightage (\%) \\
\hline $\begin{array}{c}\text { Green Facilities, } \\
\text { Operation, and } \\
\text { Maintenance, }\end{array}$ & 10 & 32 & $32 \%$ \\
\hline Water Management & 7 & 26 & $26 \%$ \\
\hline Energy Conservation, & 6 & 21 & $21 \%$ \\
\hline Waste Management & 3 & 8 & $8 \%$ \\
\hline $\begin{array}{c}\text { Resident Health \& } \\
\text { Wellbeing }\end{array}$ & 4 & 8 & $8 \%$ \\
\hline $\begin{array}{c}\text { Exceptional Green } \\
\text { Practices }\end{array}$ & 3 & 5 & $5 \%$ \\
\hline Total & 33 & 100 & $100 \%$ \\
\hline
\end{tabular}

Source: Gaurav Gangwar

The various ratings are awarded as per the following table:

Table 2. Certification Level

\begin{tabular}{|c|c|}
\hline Certification level & Recognition \\
\hline Certified & Best Practice \\
\hline Silver & Outstanding Performance \\
\hline Gold & National Excellence \\
\hline Platinum & Global Leadership \\
\hline
\end{tabular}




\subsubsection{GRIHA Rating System for Housing}

Green Rating for Integrated Habitat Assessment (GRIHA) did not have the unique rating criteria for Housing before 2017. In 2017, GRIHA published the rating criteria for "GRIHA for Affordable Housing." There are six sections available in GRIHA affordable housing rating systems such as Site Planning, Energy and Occupant Comfort, Water Saving, Waste Management, Sustainable Building Materials, Social Aspects, and Bonus Points, as shown in Table 3. There are 30 criteria and a total of 100 points under these six sections. Out of these 30 criteria, three are mandatory, eight are partially mandatory, and others are optional. [16]

Table 3. Criteria's, Points, and Weightage

\begin{tabular}{|c|c|c|c|}
\hline Sections & Criteria's & Points & Weightage (\%) \\
\hline Site Planning & 5 & 16 & $16 \%$ \\
\hline $\begin{array}{c}\text { Energy and } \\
\text { Occupant Comfort }\end{array}$ & 6 & 25 & $25 \%$ \\
\hline Water-Saving & 4 & 19 & $19 \%$ \\
\hline $\begin{array}{c}\text { Waste } \\
\text { Management }\end{array}$ & 2 & 7 & $7 \%$ \\
\hline $\begin{array}{c}\text { Sustainable } \\
\text { Building Materials }\end{array}$ & 5 & 17 & $17 \%$ \\
\hline Social Aspects & 7 & 16 & $100 \%$ \\
\hline Total & 29 & 100 & \\
\hline Bonus Points & 1 & 4 & \\
\hline Total & 30 & 104 & \\
\hline
\end{tabular}

Source: Gaurav Gangwar

The various ratings are awarded as per the following table.

Table 4. GRIHA Rating

\begin{tabular}{|c|c|}
\hline Points achieved & $\begin{array}{c}\text { Eco Housing Assessment } \\
\text { Rating }\end{array}$ \\
\hline $25-40$ & $\star$ \\
\hline $41-55$ & $\star \star$ \\
\hline $56-70$ & $\star \star \star$ \\
\hline $71-85$ & $\star \star \star \star$ \\
\hline$>86$ & $\star \star \star \star \star$ \\
\hline
\end{tabular}

\subsubsection{Eco Housing Assessment Criteria's:}

There are two versions of Eco Housing Assessment Criteria's available, version -1 and Version -II. The Eco housing assessment criteria's version -II consists of seven focus areas such as Site planning, Environmental
Architecture, Energy Conservation and Management, Efficient Building Materials, Water Conservation and Management, Solid Waste Management, and Other Measures as shown in Table 5. There are 77 measures under these six focus areas; 40 are mandatory, comprising 450 points, 37 are non-mandatory, comprising 550 points. [17]

Table 5. Criteria's, Points, and Weightage

\begin{tabular}{|c|c|c|c|c|}
\hline Focus Area & Mandatory & $\begin{array}{c}\text { Non } \\
\text { Mandatory }\end{array}$ & Total & $\begin{array}{c}\text { Weightage } \\
(\%)\end{array}$ \\
\hline Site Planning & 90 & 50 & 140 & $32 \%$ \\
\hline $\begin{array}{c}\text { Environmental } \\
\text { Architecture }\end{array}$ & 50 & 30 & 80 & $8 \%$ \\
\hline $\begin{array}{c}\text { Energy } \\
\text { Conservation }\end{array}$ & 65 & 175 & 240 & $24 \%$ \\
\hline $\begin{array}{c}\text { Efficient } \\
\text { Building } \\
\text { Materials }\end{array}$ & 30 & 160 & 190 & $19 \%$ \\
\hline $\begin{array}{c}\text { Water } \\
\text { Conservation }\end{array}$ & 95 & 55 & 150 & $15 \%$ \\
\hline $\begin{array}{c}\text { Solid Waste } \\
\text { Management }\end{array}$ & 75 & 45 & 120 & $12 \%$ \\
\hline $\begin{array}{c}\text { Other } \\
\text { Measures. }\end{array}$ & 45 & 35 & 80 & $8 \%$ \\
\hline Total & 450 & 550 & 1000 & $100 \%$ \\
\hline
\end{tabular}

Source: Eco Housing Assessment Criteria’s Manual

It is very clear from the above table that the maximum points achievable are 1000 points and minimum 500 points required for certification under Eco housing Assessment Criteria's as shown in Table 6 [17]

Table 6. Eco Housing Assessment Rating

\begin{tabular}{|c|c|}
\hline Points achieved & $\begin{array}{c}\text { Eco Housing Assessment } \\
\text { Rating }\end{array}$ \\
\hline $500-600$ & $\star$ \\
\hline $601-700$ & $\star \star$ \\
\hline $701-800$ & $\star \star \star$ \\
\hline $801-900$ & $\star \star \star \star$ \\
\hline$>900$ & $\star \star \star \star \star$ \\
\hline
\end{tabular}

Source: Eco Housing Assessment Criteria's Manual

\subsubsection{Comparative Analysis of Rating Systems: An Overview}

The rating system's comparative analysis of the focused area is given below to understand all three rating systems' similarity and dissimilarity, as shown in Table 7. 
Table 7. Comparative Analysis of Rating system

\begin{tabular}{|c|c|c|c|}
\hline Focus Area & $\begin{array}{c}\text { Eco housing assessment Criteria's } \\
\text { Weightage (\%) }\end{array}$ & $\begin{array}{c}\text { GRIHA } \\
\text { Weightage (\%) }\end{array}$ & $\begin{array}{c}\text { IGBC } \\
\text { Weightage (\%) } \\
\end{array}$ \\
\hline Site Planning & $14 \%$ & $16 \%$ & $\begin{array}{c}32 \% \\
\text { Include building materials } \\
\end{array}$ \\
\hline Environmental Architecture & $8 \%$ & - & - \\
\hline Energy Conservation & $24 \%$ & $\begin{array}{c}25 \% \\
\text { Include occupant comfort }\end{array}$ & $21 \%$ \\
\hline Sustainable Building Materials & $19 \%$ & $17 \%$ & - \\
\hline Water Conservation & $15 \%$ & $19 \%$ & $26 \%$ \\
\hline Waste Management & $12 \%$ & $7 \%$ & $8 \%$ \\
\hline Other Measures. & $8 \%$ & - & - \\
\hline Social Aspects & - & $16 \%$ & - \\
\hline Resident health and well being & - & - & $8 \%$ \\
\hline Exceptional Green practices & - & - & $5 \%$ \\
\hline Total & $100 \%$ & $100 \%$ & $100 \%$ \\
\hline
\end{tabular}

Source: Gaurav Gangwar

It is concluded that four focus areas tend to be similar and that other focus areas are different. The Sustainable Building Materials are standard in two rating systems, and it can be included as one more focus area. Hence, five common focused areas will be studied in the rating system, and all other focus areas will be put as a Miscellaneous category. There will also be a similarity and dissimilarity between different rating systems for the selected five focus areas that will be addressed while generating design principles for sustainable housing in the next section.

\subsection{Principles of Design for Sustainable Housing in India Based on Detailed Comparative Analysis of Various Rating System in India}

The analysis of the rating system suggests that not all three rating systems have the same standards for housing ratings. Many criteria are similar in all three rating agencies, and many are entirely different. All criteria need to be included in the Principles of Design for Housing so that specific housing is suitable for sustainable housing under all three rating systems. There are five core design-focused areas, i.e., site preparation, energy consumption and daylighting, sustainable building materials, water conservation, waste management, and the other focused area will be put in under the Miscellaneous head Categories.

\subsubsection{Site Planning}

\subsubsection{Selection of Site}

The various criteria related to the Selection of sites of all three rating systems are shown in Table 8 .
Table 8. Criteria's for Site Selection

\begin{tabular}{|c|l|}
\hline Rating system & \multicolumn{1}{|c|}{ Criteria } \\
\hline GRIHA & \multicolumn{1}{|c|}{ Nil } \\
\hline IGBC & $\begin{array}{l}\text { Ensure access to basic amenities to reduce } \\
\text { negative impacts caused to the Environment } \\
\text { from automobile use. }\end{array}$ \\
\hline \multirow{5}{*}{ Eco Housing } & $\begin{array}{l}\text { To protect parkland, forest, coastal belt, and } \\
\text { eco-sensitive zones from disturbance due to } \\
\text { construction and to protect biodiversity. } \\
\text { To discourage the use of vehicles for common } \\
\text { chores thus saving fuel energy on } \\
\text { transport emengency healthcare facilities }\end{array}$ \\
$\begin{array}{l}\text { Ensure emergen } \\
\text { Convenience }\end{array}$ \\
\hline
\end{tabular}

Source: IGBC, GRIHA, Eco Housing Assessment Criteria's Manual

Design Principles:

i. The Selection of the site is not necessarily in the owner or the architect's hands since there are so many other factors that control it. But if the option is made, the site should be chosen in such a way as to create a construction that does not disrupt the natural environment.

ii. The site should be located within $1 / 2 \mathrm{Km}$ radius of the bus stop, commuter rail, metro, etc.

iii. If the housing is more than 200 dwellings, the Healthcare facilities, grocery shops, and community hall should be provided within site. These amenities may be shared with other small housing projects in the vicinity.

\subsubsection{Natural Features, Landscaping, and Soil Conservation}

The various criteria related to Natural Features, Landscaping, and Soil Conservation of all three rating systems are shown in Table 9. 
Table 9. Criteria's of Natural features, landscaping, and soil conservation

\begin{tabular}{|c|c|}
\hline Rating system & Criteria \\
\hline GRIHA & $\begin{array}{l}\text { Ensure that no existing mature tree is cut on-site. OR Transplant mature trees within the site and ensure their } \\
\text { survival. OR Plant } 3 \text { trees of native/naturalized species for every } 1 \text { tree cut. OR Any combination of these for } \\
\text { all existing mature trees on site. } \\
\text { Increase the total number of trees on-site by } 25 \% \text { above the pre-construction phase. OR Plant } 4 \text { trees of } \\
\text { native/naturalized species for every } 1 \text { tree cut. } \\
\text { Preserve topsoil during construction; maintain its fertility (during the construction phase) and use for } \\
\text { landscape post-construction. }\end{array}$ \\
\hline IGBC & Encourage greenery within the site, thereby preserving the local habitat and promoting biodiversity \\
\hline Eco Housing & $\begin{array}{l}\text { i. Biodiversity Conservation and Preservation Protect vegetation, Carbon Sequestration, Reduce soil erosion, } \\
\text { Compensate for the removed vegetation } \\
\text { ii. To preserve and reuse nutrient-rich topsoil for landscaping, To encourage organic landscaping and waste } \\
\text { recycling }\end{array}$ \\
\hline
\end{tabular}

Source: IGBC, GRIHA, Eco Housing Assessment Criteria’s Manual

\section{Design Principles:}

i. The landscape plan should be prepared, showing the existing tree, trees to be cut and the planned trees, other features such as water sources, green areas, etc. The tree should be planted in such a way as to take into consideration the microclimate of the site.

ii. The planning and construction should be carried out in such a way as to retain natural elements such as dense tree clusters, water sources, topographical features such as steep slopes, or peaks.

iii. The plants may be removed for construction; they may be transplanted if necessary. If it is appropriate to remove a few trees, the new trees must be planted at a ratio of 1:5.

iv. The topsoil is very important to preserve because It has fertile value for all types of vegetation. During the construction, this topsoil should be preserved at some location and used for vegetation later on.

\subsubsection{Utility Corridor and Site Circulation}

The various criteria related to the Utility Corridor and site circulation of all three rating systems are shown in Table 10

Table 10. Criteria's of utility corridor and circulation

\begin{tabular}{|l|l|}
\hline \multicolumn{1}{|c|}{ Rating system } & \multicolumn{1}{|c|}{ Criteria } \\
\hline GRIHA & Nil \\
\hline IGBC & Nil \\
\hline Eco Housing & $\begin{array}{l}\text { To facilitate easy maintenance and } \\
\text { minimize site disruption }\end{array}$ \\
\hline
\end{tabular}

Source: IGBC, GRIHA, Eco Housing Assessment Criteria’s Manual

\section{Design Principles:}

i. The roads and pedestrian walkways are designed in such a way as to reduce the length by careful planning, and a separate utility corridor should be provided for utility services.

ii. Utility systems such as sewage disposal, power, water, telecommunication, stormwater, etc. should be kept a distance as per local code/ norms.

\subsubsection{Mitigating Heat Island Effect}

The various criteria related to Mitigating Heat Island Effect of all three rating systems are shown in Table 11.

Table 11. Criteria's of Mitigating Heat Island Effect

\begin{tabular}{|l|l|}
\hline Rating system & \multicolumn{1}{|c|}{ Criteria } \\
\hline GRIHA & $\begin{array}{l}\text { To ensure incorporation of site design strategies } \\
\text { which assist in the reduction of hard paving } \\
\text { on-site to mitigate Urban Heat Island Effect }\end{array}$ \\
\hline IGBC & $\begin{array}{l}\text { Reduce heat islands to minimize the impact on } \\
\text { microclimate, human, and local biodiversity. }\end{array}$ \\
\hline Eco Housing & $\begin{array}{l}\text { To reduce the microclimate } \\
\text { temperature rise. }\end{array}$ \\
\hline
\end{tabular}

Source: IGBC, GRIHA, Eco Housing Assessment Criteria's Manual

Design Principles:

i. The hard surface should be reduced to minimize the heat impact of the island; at least 50 percent of the surface should have pervious pavements / open grid pavements/grass pavements.

ii. Surface shading is essential to minimize the heat effect of the island; at least 50 percent of non-roof impervious surfaces should be shaded on-site, including parking lots, walkways, and plazas.

iii. At least 50 percent of the overall paved surface of the area should have a reflectance of .5 .

\subsubsection{Renewable Energy Sources}

The various criteria related to Renewable Energy sources of all three rating systems are shown in Table 12.

Table 12. Criteria's of renewable energy sources

\begin{tabular}{|c|c|}
\hline $\begin{array}{l}\text { Rating } \\
\text { system }\end{array}$ & Criteria \\
\hline GRIHA & $\begin{array}{l}\text { i. To promote the use of energy-efficient } \\
\text { lighting in outdoor spaces and indoor } \\
\text { common areas. } \\
\text { To promote the use of energy-efficient } \\
\text { ii. equipment }\end{array}$ \\
\hline IGBC & $\begin{array}{l}\text { Reduce light pollution to increase night sky access and } \\
\text { enhance the nocturnal Environment. }\end{array}$ \\
\hline $\begin{array}{l}\text { Eco } \\
\text { Housing }\end{array}$ & $\begin{array}{l}\text { To reduce energy usage for site lighting } \\
\text { To prevent light pollution of the night sky } \\
\text { and light trespass into adjacent property } \\
\text { To minimize wastage of lighting during } \\
\text { unoccupied hours }\end{array}$ \\
\hline
\end{tabular}

Source: IGBC, GRIHA, Eco Housing Assessment Criteria's Manual 
Design Principles:

i. There should be a proper use of efficient lighting sources for outdoor lighting, and this lighting should utilize renewable energy sources like solar panels, wind towers, etc.

ii. There should be renewable energy sources of $1 \mathrm{kWp}$ per $500 \mathrm{sqm}$ of total built-up area.

iii. All motors and transformer should be at least a 3-star BEE rating.

iv. Automation is recommended for outdoor lighting to minimize the saving of energy.

v. It is highly recommended that the lighting fixture be used not to create light pollution, which may not be suitable for humans, trees, and animals. For more significant projects, a lighting consultant should be appointed.

vi. The solar water heater should be used in the Housing campus and other similar projects per project requirements.

\subsubsection{Energy Consumption and Daylighting}

The various criteria related to Energy Consumption and Daylighting of all three rating systems are shown in Table 13.

Table 13. Criteria's of Energy Consumption and Daylighting

\begin{tabular}{|l|ll|}
\hline \multicolumn{1}{|c|}{$\begin{array}{c}\text { Rating } \\
\text { system }\end{array}$} & Criteria \\
\hline GRIHA & i. $\begin{array}{l}\text { To ensure thermal comfort by minimizing } \\
\text { the overall heat gain from the envelope } \\
\text { through suitable construction materials } \\
\text { and optimal fenestration design } \\
\text { To harness the available daylight and } \\
\text { provide adequate, equally distributed, and } \\
\text { diffused daylight for better visual comfort. }\end{array}$ \\
\hline IGBC & i. $\begin{array}{l}\text { Avoid the use of refrigerants and } \\
\text { ozone-depleting gases which have a } \\
\text { negative impact on the environment. } \\
\text { Optimize lighting energy consumption, to } \\
\text { reduce negative environmental impacts } \\
\text { from excessive energy use. } \\
\text { Promote self-sufficiency in energy } \\
\text { through renewable technologies, to } \\
\text { minimize the environmental impacts } \\
\text { associated with the use of fossil fuel } \\
\text { energy }\end{array}$ \\
\hline Eco & ii. $\begin{array}{l}\text { To enable energy efficiency, thermal and visual } \\
\text { Housing }\end{array}$ \\
\hline
\end{tabular}

Source: IGBC, GRIHA, Eco Housing Assessment Criteria's Manual

Design Guidelines:

i. The sun and wind are the most plentiful sources of nature available free of charge. The blocks should be oriented in such a way as to have a favorable orientation for most of the blocks. For particular latitude and longitude, a favorable orientation should be worked out.

ii. The orientation of blocks should also be done to viii. allow optimize the wind flow in all units. iii. The distance between blocks should be calculated to allow winter sun and stop the summer sun. The mutual shading and self-shading of blocks should be worked to ensure minimizing the heat gain in summers.

iv. The units should be oriented in such a manner to reduce heat gain in summer and allow heat gain in winter.

v. The surface to volume and perimeter to area ratio should be calculated, and it should be minimum to have a less exposed area in a hot climate.

vi. The staircase, toilets, etc. should act as buffer spaces to reduce heat gain for the main areas such as living, dining, bedrooms, etc. in summers.

vii. The window size should be determined based on the amount of light required and the amount of wind needed in a building.

viii. The shading of the window and another opening should be done as solar path analysis.

ix. All areas should be designed in such a manner to receive a sufficient amount of light. 1 daylight factor $=80$ lux. Kitchen $=2.5$ Living $=.625$ Study Room $=1.9$ Circulation $=.313$ etc.

x. The computer simulation tools may be used to check thermal comfort by measuring the airflow, temperature, and humidity.

\subsubsection{Sustainable Building Materials}

The various criteria related to Sustainable Building Materials of all three rating systems are shown in Table 14.

Design Guidelines:

i. The used materials should have low embodied energy.

ii. The life cycle assessment of materials should be compared in selecting the materials.

iii. The material should be environmentally friendly and do not harm the environment. The used material to have low carbon emissions and comparative analysis should be done before selecting the material.

iv. The $R$-value and $U$ value are significant in selecting the materials so that these can act as good insulation materials

v. The use of pozzolana material along with cement for R.C.C and other purposes should be encouraged.

vi. Alternative structural systems such as Ferro cement and/or pre-cast components should be used for columns, beams, slabs, staircases, lofts, balconies, and roof.

vii. The convention bricks should be avoided, and the alternate building materials should be used, e.g., fly ash bricks, lime bricks, industrial waste bricks, aerated lightweight concrete blocks, gypsum-based blocks, lato blocks, etc

The use of natural wood should be avoided, and the new low energy, recycled material should be used. 
Table 14. Criteria's of Sustainable Building Materials

\begin{tabular}{|c|c|c|}
\hline Rating system & & Criteria \\
\hline GRIHA & $\begin{array}{l}\text { i. } \\
\text { ii. } \\
\text { iii. }\end{array}$ & $\begin{array}{l}\text { To reduce the environmental impact of construction by utilizing environment-friendly construction } \\
\text { materials or technologies that use waste material or have recycled content or have low embodied energy } \\
\text { To promote the installation of low environmental impact materials in the building interiors and reduce the } \\
\text { usage of virgin material. } \\
\text { To promote the use of low-VOC and lead-free interior paints; low-VOC adhesives and sealants; } \\
\text { composite wood product without urea-formaldehyde to maintain good indoor air quality for the } \\
\text { occupants. }\end{array}$ \\
\hline IGBC & ii. & $\begin{array}{l}\text { Use certified green building materials, products, and equipment, to reduce dependence on materials that } \\
\text { have associated negative environmental impacts } \\
\text { Provide occupants with descriptive guidelines that educate and help them implement and maintain green } \\
\text { design features }\end{array}$ \\
\hline Eco Housing & $\begin{array}{l}\text { i. } \\
\text { ii. } \\
\text { iii. } \\
\text { iv. }\end{array}$ & $\begin{array}{l}\text { To reuse /recycle waste products and prevent landfills. } \\
\text { To reuse/recycle waste Products } \\
\text { To reuse /recycle waste products and prevent landfills. } \\
\text { To use lesser quantities of materials and to reduce site wastages, thus reducing the amount of resource } \\
\text { extraction. To promote the use of traditional/vernacular construction techniques } \\
\text { To use energy-efficient building material and materials from renewable sources }\end{array}$ \\
\hline
\end{tabular}

Source: IGBC, GRIHA, Eco Housing Assessme nt Criteria's Manual

Table 15. Criteria's of water conservation

\begin{tabular}{|c|c|c|}
\hline $\begin{array}{l}\text { Rating } \\
\text { svstem }\end{array}$ & & Criteria \\
\hline GRIHA & iii. & $\begin{array}{l}\text { To minimize the requirement of potable water during construction by deploying effective construction management } \\
\text { practices on site } \\
\text { To reduce the overall water demand of the building through system optimization, which includes the installation of } \\
\text { water-efficient systems such as low flush toilets equipped with dual flush functionality and water faucets with } \\
\text { aerators. Additionally, this criterion emphasizes on reducing the landscape water demand through the use of } \\
\text { regionally appropriate, xerophyte (low water using native species of flora) plant species and efficient irrigation } \\
\text { systems } \\
\text { To ensure the availability of appropriate facilities for tertiary- level treatment of wastewater generated, artificial } \\
\text { groundwater recharge and rainwater storage; and maximum utilization of treated and harvested water within the } \\
\text { project site to reduce the overall dependence on freshwater supply from concerned authorities } \\
\text { To ensure that a monitoring mechanism is in place for the supply of freshwater from concerned authority and at STP } \\
\text { outlet line }\end{array}$ \\
\hline IGBC & $\begin{array}{l}\text { i. } \\
\text { ii. } \\
\text { iii. } \\
\text { iv. } \\
\text { v. } \\
\text { vi. }\end{array}$ & $\begin{array}{l}\text { Enhance groundwater table and reduce municipal water demand through effective rainwater management } \\
\text { Encourage continuous monitoring to enhance the water performance of the residential society, thereby save potable } \\
\text { water } \\
\text { Measure and reduce the per capita water consumption in the residential society, thereby saving potable water } \\
\text { Enhance the efficiency of water fixtures, thereby minimizing potable water use } \\
\text { Treat wastewater generated on-site, to avoid polluting the receiving streams by safe disposal and reduce the burden } \\
\text { on Centralised municipal water treatment plants } \\
\text { Reuse of treated wastewater to meet the Landscaping / Flushing demand or both. }\end{array}$ \\
\hline $\begin{array}{l}\text { Eco } \\
\text { Housing }\end{array}$ & $\begin{array}{l}\text { i. } \\
\text { ii. } \\
\text { iii. } \\
\text { iv. } \\
\text { v. } \\
\text { vi. } \\
\text { vii. } \\
\text { viii. }\end{array}$ & $\begin{array}{l}\text { Reduce water consumption } \\
\text { Minimize water use } \\
\text { Reduce water consumption } \\
\text { Rain Water Harvesting } \\
\text { Treatment Of Grey And Black Waste Water } \\
\text { Reuse of treated Greywater } \\
\text { Minimizing the water during construction } \\
\text { Reduce water consumption for landscaping }\end{array}$ \\
\hline
\end{tabular}

Source: IGBC, GRIHA, Eco Housing Assessment Criteria's Manual

\subsubsection{Water Conservation}

The various criteria related to Water Conservation of all three rating systems are shown in Table 15.

Design Guidelines:

i. Rainwater harvesting should be done as applicable in a particular area. The water should be accumulated in a rainwater storage tank and may be utilized for different purposes such as flush, landscaping, etc. Recharge pits may be worked out so that stormwater may be discharged in these pits to increase the area's underground water table.

ii. The greywater and black water of sewage may also be treated in a treatment plant. The water should be reused after treatment for various purposes such as flushing and landscape etc.

iii. The water consumption should be minimized during the construction. 
iv. All fixtures and faucets should have low flow rates not exceeding 81pm.

v. All W.C to be provided with a dual flush system to avoid wastage of water.

vi. The native species should be planted to consume less water, and the gardening area should be minimized to reduce the water for landscaping.

vii. There should be a sprinkler and drip irrigation system for outdoor landscape areas to reduce water consumption.

\subsubsection{Waste Management}

The various criteria related to Waste Management of all three rating systems are shown in Table 16.

Table 16. Criteria's of Waste Management

\begin{tabular}{|c|c|c|}
\hline $\begin{array}{l}\text { Rating } \\
\text { system }\end{array}$ & & Criteria \\
\hline GRIHA & ii. & $\begin{array}{l}\text { To ensure Segregation, safe storage, } \\
\text { recycle, reuse, and disposal of construction } \\
\text { waste during construction } \\
\text { To adopt and implement sustainable solid } \\
\text { waste management strategies and provide } \\
\text { appropriate infrastructure on site for } \\
\text { collection, Segregation, storage, and } \\
\text { disposal of solid waste during the } \\
\text { operation phase; and to promote \& provide } \\
\text { infrastructure facilities for treatment of } \\
\text { segregated organic/biodegradable waste on } \\
\text { site }\end{array}$ \\
\hline IGBC & ii. & $\begin{array}{l}\text { Facilitate Segregation of waste at source to } \\
\text { encourage reuse or recycling of materials, } \\
\text { thereby avoiding waste being sent to } \\
\text { landfills } \\
\text { Ensure effective organic waste } \\
\text { management, so as to prevent waste being } \\
\text { sent to landfills. } \\
\text { Ensure effective dry waste management, } \\
\text { so as to prevent waste being sent to } \\
\text { landfills. }\end{array}$ \\
\hline $\begin{array}{l}\text { Eco } \\
\text { Housing }\end{array}$ & iv. & $\begin{array}{l}\text { To efficiently manage wastes and recover } \\
\text { resources, Segregation of waste at source/ } \\
\text { Reduce the quantity of waste to be } \\
\text { collected by the local urban body, To adopt } \\
\text { scientific methods for designs of collection } \\
\text { /storage bins from a public health point of } \\
\text { view. } \\
\text { To efficiently manage the wastes and } \\
\text { recover resources. } \\
\text { To promote ' Zero Wet Waste' concept To } \\
\text { efficiently manage the wastes and recover } \\
\text { resources } \\
\text { To promote the ' Zero Wet Waste' concept } \\
\text { and Recover resource }\end{array}$ \\
\hline
\end{tabular}

Source: IGBC, GRIHA, Eco Housing Assessment Criteria’s Manual
Design Guidelines:

a). There should be Segregation of solid waste and other waste at the source.

b). There should be a proper procedure to be worked out to collect the waste, and the schedule must be worked out to dispose of different kinds of waste.

c). On-site treatment of organic waste should be done in large housing complexes. Energy and manure should be recovered from waste.

d). Construction waste should be utilized on-site as much as possible.

e). Spill prevention and control plans should be made to stop the source of the spill, contain the spill, and dispose of the hazardous waste and contaminated materials.

\subsubsection{Miscellaneous}

Design Guidelines:

a). There should be proper safety measure during the constructions for workers

b). The noise control and air pollution should be taken care of at the time of construction activity.

c). There should not be any contamination of the water table and a minimum standard of living for construction workers.

d). There should be at least two techniques to reduce water consumption during construction, such as using treated water or rainwater for construction activities or using an additive to reduce the curing water.

e). To promote the adoption of a measure for the project to make it universally accessible.

f). To create awareness of sustainability among the residents and visitors.

g). There should be proper sanitation /safety of construction workers on-site, and there should be an appropriate mechanism to reduce the air pollution on-site during construction.

\subsection{Case Studies: Applications of Principles of Design for Sustainable Housing in India}

The three case studies were chosen to analyze the applications of the derived Principles of Design (as mentioned in the last section) for a housing project; the first case study Tzed homes, Bangalore, is considered to be a live study due to site visits and interactions with users of by author; the other two case studies are conducted through the internet.

\subsubsection{Case Study 1: Tzed Homes, Bangalore (Live Study)}

The project statistics of T-ZED Homes, Bangalore, are shown in Table 17. 
Table 17. Project statistics of Tzed Homes

\begin{tabular}{|c|c|}
\hline Occupancy Type & Residential Apartments \\
\hline Built-up area & 4558.14 sqm \\
\hline Site Area & 19685.0 sqm (5 Acres) \\
\hline Completed & 2006 \\
\hline Location & Airport Whitefield Road Bangalore \\
\hline Principal Architect & $\begin{array}{c}\text { Sanjay Prakash \& Associates (SP\&A), } \\
\text { now Studio for Habitat Futures }\end{array}$ \\
\hline Green consultant & En3 Sustainability Solutions \\
\hline Rating System & GREEN HOMES \\
\hline Rating Achieved & PLATINUM \\
\hline
\end{tabular}

Source: Architecture +Design, Nov 2008

\subsubsection{Site Planning}

a). The site is very well connected to public facilities in terms of transportation. It is $2 \mathrm{~km}$ from the main road and $2.5 \mathrm{~km}$ from the main bus stop of Ramagondanahali.

b). The project retains the natural topography of up to $39.94 \%$ of the site area. As one approach to this housing, one reached the parking stilt area- 8 ' 0 "below the road level, it is due to the preservation of the natural topography as shown in Fig 1[18]

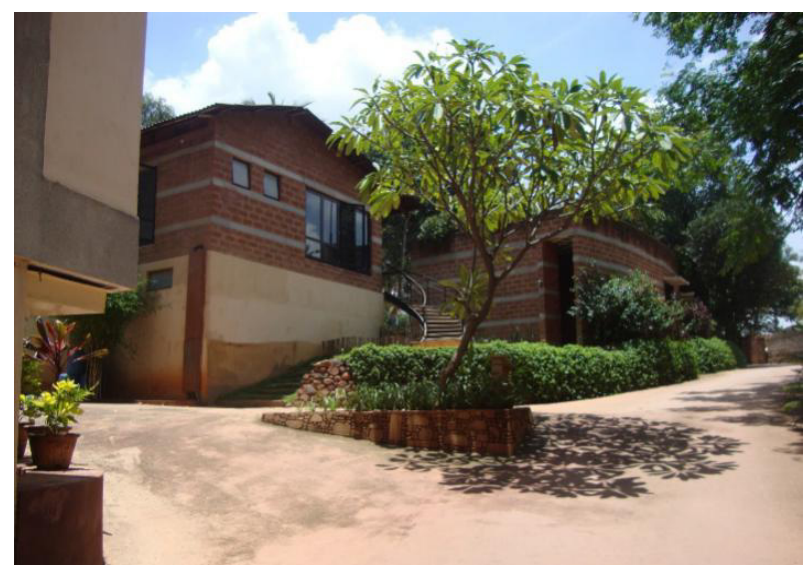

Source: Gaurav Gangwar

Figure 1. View showing retaining the natural Topography of Land

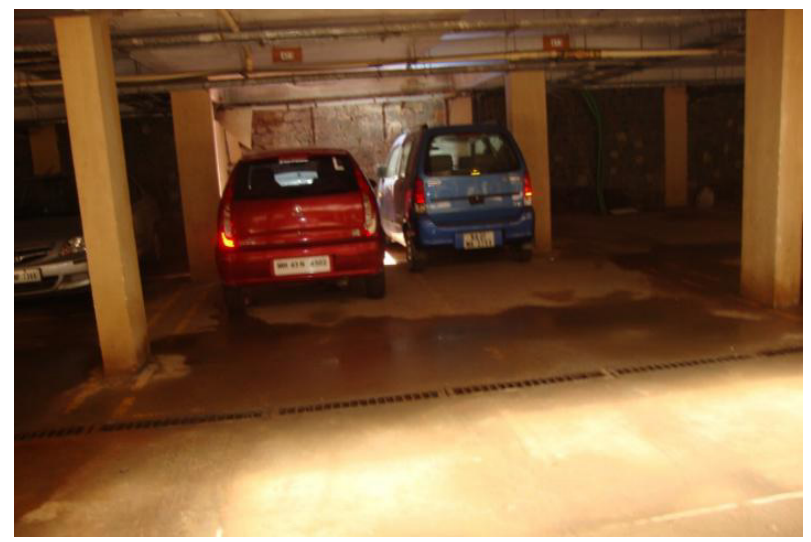

Source: Gaurav Gangwar

Figure 2. View showing lighting and ventilation in parking

c). Parking level:
The parking is offered in the sunken courtyard, open on the driveway, and connected to other sections of the ground. It did not feel like a basement, and no artificial means are required for lighting and ventilation at this parking level, as shown in Fig 2. This can be considered a good save on electricity than parking in the basement, causing more electricity usage. [18]

\section{d). Landscaping:}

The site is very linear. The plot is divided into two zones, the north zone, and the south zone, by a road on the central axis. In the southern section, the blocks are deliberately situated a little farther apart, and the landscape areas have been worked out between the blocks, called the e-zone, as shown in Fig 3 \& Fig 4. There are recreational zones for children's games, seating areas, etc. Thick vegetation and other features of the landscape are planted in this area. [19]

Fire tender road is a mandatory requirement all around the site, and it can be used only in case of fire. This fire tender road is almost at the road level of entrance, so the residents do not use it for parking. This road is landscaped so that only the part of the wheel is paved, and the in-between space is treated with grass, as shown in Fig 5.

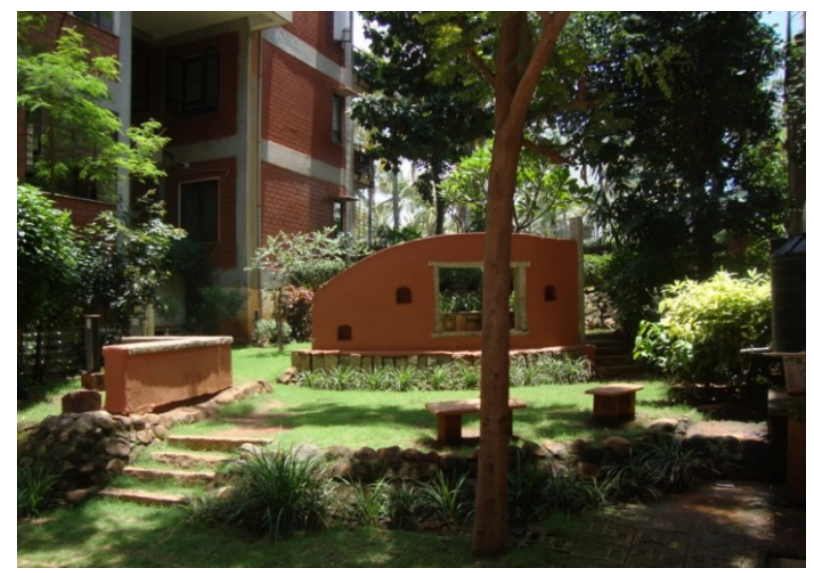

Source: Gaurav Gangwar

Figure 3. Landscape areas between the blocks on the Sothern side for playing of kids

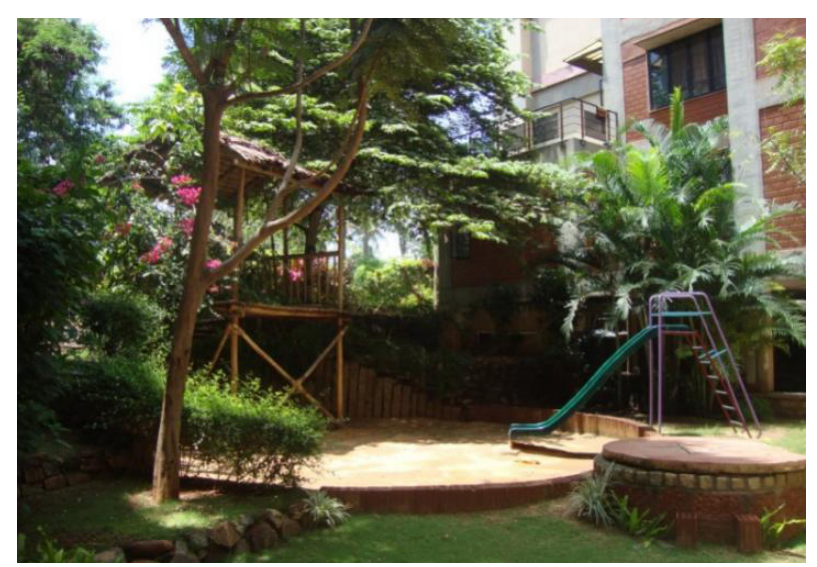

Source: Gaurav Gangwar

Figure 4. Landscape areas between the blocks on the Sothern side for sitting purposes 


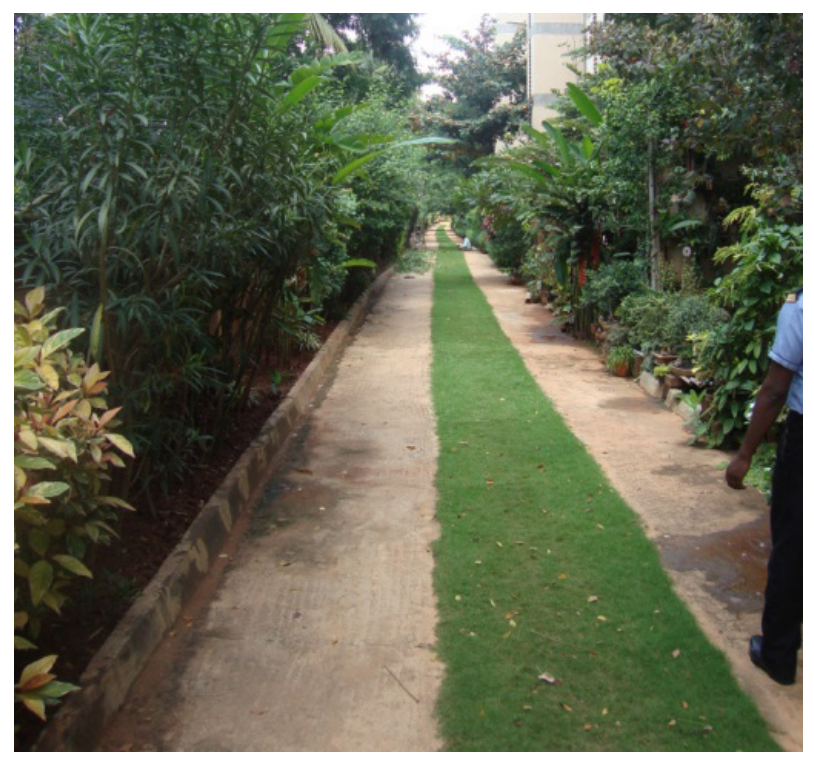

Source: Gaurav Gangwar

Figure 5. Landscape of Fire tender road

\subsubsection{Resource Management}

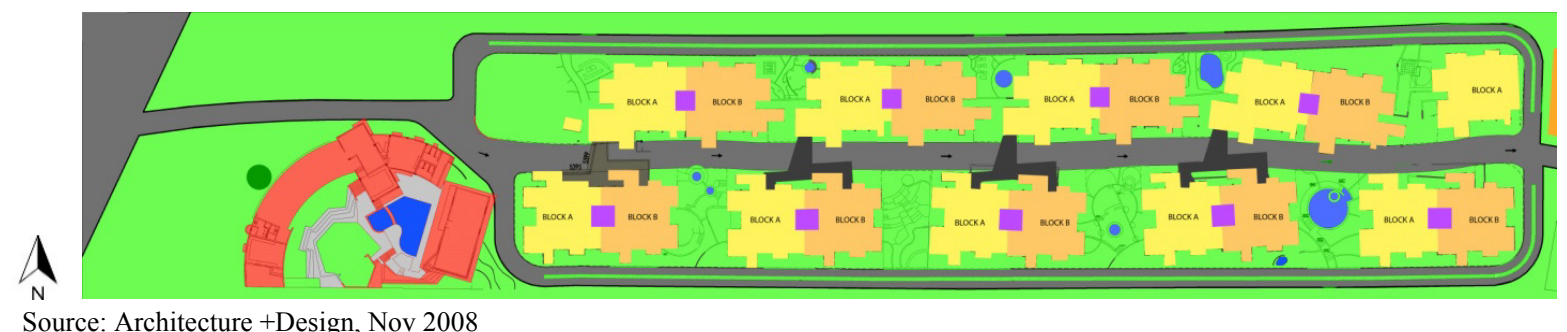

Figure 6. Ground floor of Tzed Homes

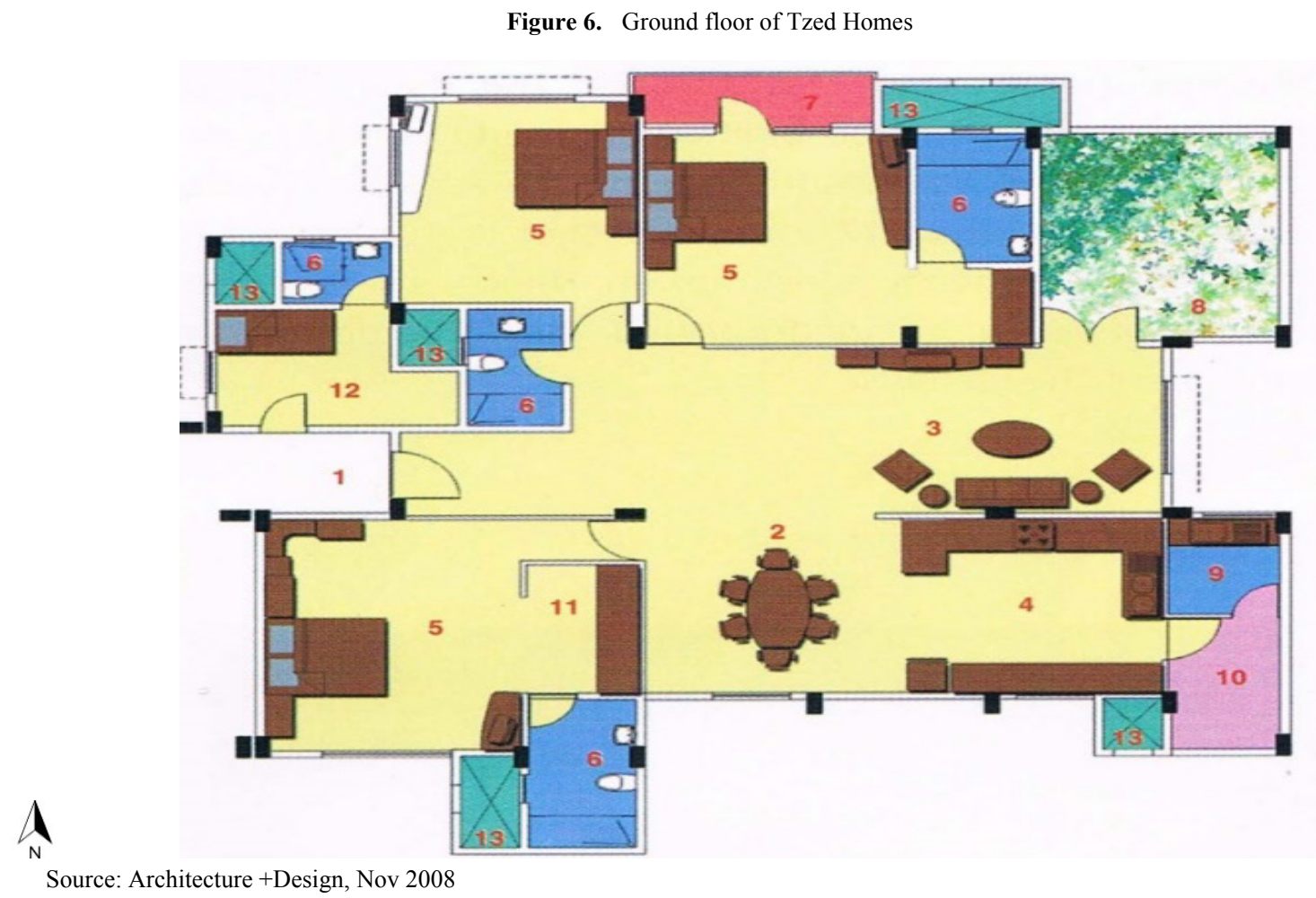

Figure 7. Plan of Flat
$75 \%$ of the total construction waste is recycled or reused on-site, which is an excellent achievement and also reduced the construction cost. Approximately $82 \%$ of the total material used was manufactured and extracted regionally to minimize transport costs and reduce environmental pollution. [18]

\subsubsection{Energy Consumption and Day Lighting}

The design of the building is incorporating passive principles of design to ample daylight available at every home. [19] The orientation of the four-story blocks is so that the longer axis is facing north-south, and the opening in the units is facing north and south, as shown in Fig 6. This will allow for less heat gain in the summer and more heat gain in the winter. This will also affect the lower energy usage within the building. [18]

The unit plans' arrangement has more opening of the room faces to the north and south, as shown in Fig 7. There is a bedroom, a dining room, a kitchen on the south side, a living room facing east, and the other rooms facing north. This also allows the proper daylighting in all rooms, and $87 \%$ of regularly occupied spaces have necessary daylight. [18] 


\subsubsection{Sustainable Building Materials}

The soil stabilized blocks, laterite blocks are used on exterior walls that provide good thermal insulation and long-lasting materials, as shown in Fig 8. To reduce cement and steel used, filler slabs are used in the roof and fly ash blocks. Rubberwood, non-forest wood, is used in place of natural wood for door shutters and flooring. These are local materials that use less incarnated energy and are very useful for reducing carbon emissions. This has saved roughly 20,000 tonnes of carbon emissions in savings capital and 1500 tonnes of carbon emissions in operational savings. This may be the first residential project to seek credit from CER, as stated by BCIL. [19]

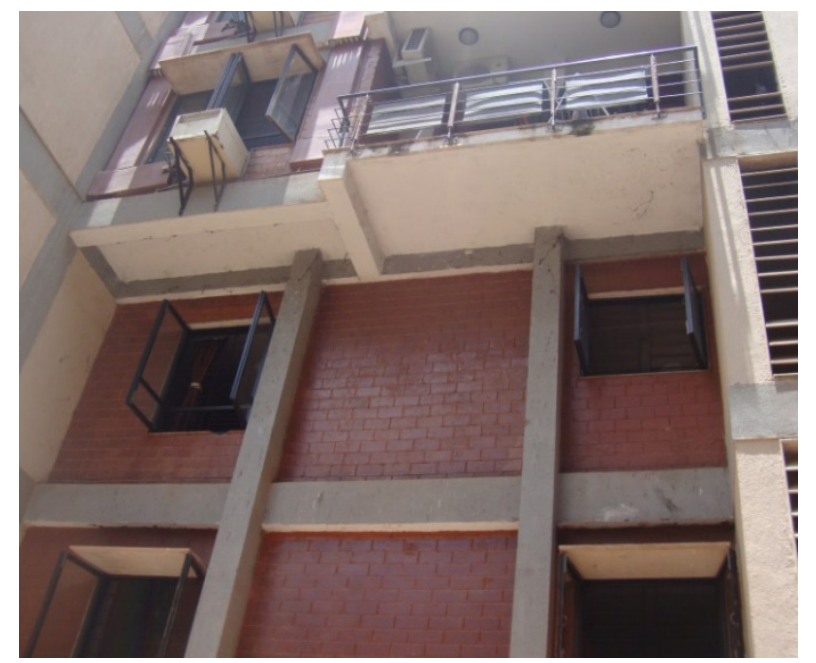

Source: Gaurav Gangwar

Figure 8. Use of building materials in Tzed homes

\subsubsection{Water Conservation}

There is no sewage connection on this campus. All black water from the toilet and bathroom continues to the sewage treatment system, where the decomposition of $70 \%$ of the biological matter is by anaerobic processes, as shown in Fig 9. [19]

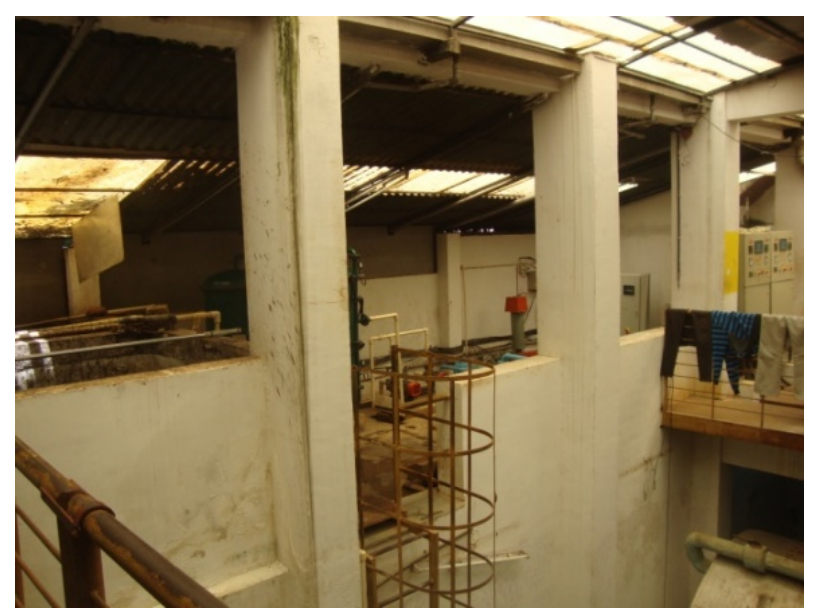

Figure 9. Sewage Treatment Plant

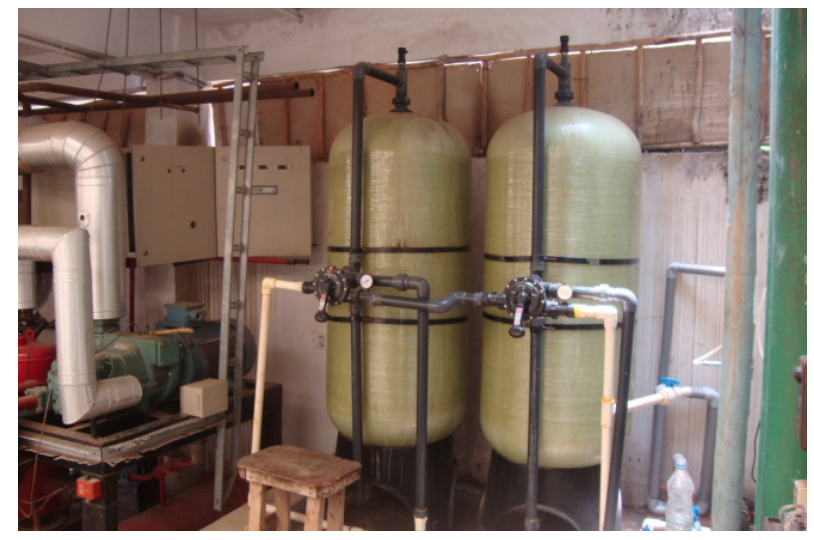

Source: Gaurav Gangwar

Figure 10. Waste Water Treatment Plant

All wastewater (greywater) is treated in the plant, as shown in Fig 10, filtration, aeration, and ozonization. This usage of treated wastewater is in the water closet of individual housing units and gardens. $95 \%$ of the wastewater is reused. [17] Low-flow dual-flush toilets, sensor-based urinals, and other low-flow fixtures are installed to minimize water consumption by $20 \%$. [19, 20]

\subsubsection{Solid Waste Management}

Solid waste segregation is done as per the different categories of waste, as shown in Fig 11. The first category of waste is plastic, metal, and tetra pack; second is paper and cardboard, third is newspapers, fourth is digester (kitchen waste), the fifth is e-waste, and sixth is glass bottles. A proper schedule worked out the collection of different categories of waste. The digester is collected daily, and e-waste is collected only once a month. Similarly, the other schedule has been worked out for other waste categories. [21]

The waste from the kitchen is divided into two parts: organic and inorganic waste. Organic waste goes to vermicomposting pits where it has been processed into Vermicompost, a nutrient-rich natural fertilizer, and a soil conditioner. This fertilizer is used in the garden. [19, 20]

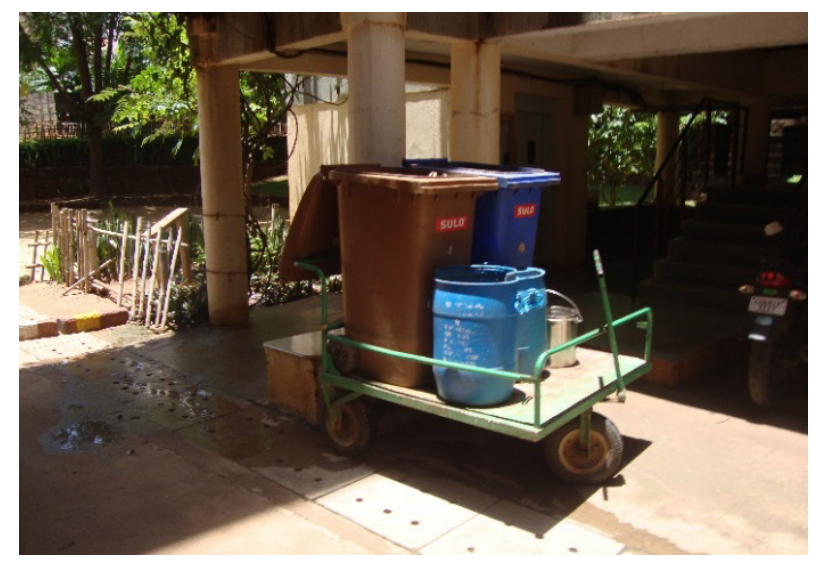

Source: Gaurav Gangwar

Figure 11. Container for Solid Waste Management 


\subsubsection{Case Study 2: Palladio, Pune (Internet Study)}

The project statistics of Palladio Pune are shown in Table 18.

Table 18. Project statistics of Palladio, Pune

\begin{tabular}{|c|c|}
\hline Occupancy Type & Residential Apartments \\
\hline Built-up area & $14,223.61 \mathrm{sqm}$ \\
\hline Site Area & $15994.32 \mathrm{sqm}$ ( 4 Acres) \\
\hline Completed & 2014 \\
\hline Location & Tathawade, Pune \\
\hline Principal Architect & VK: an architecture \\
\hline Green consultant & VK:e environmental LLP \\
\hline Rating System & GRIHA \\
\hline Rating Achieved & 4 Star Provisional GRIHA Rating \\
\hline
\end{tabular}

Source: GRIHA

\subsubsection{Site Planning}

For soil erosion control on-site, appropriate measures have been adopted, and the fertile topsoil was preserved for the use of vegetation. The existing mature trees have been protected and preserved on site. The services are planned in such a manner to create a minimum disturbance on site. [22]

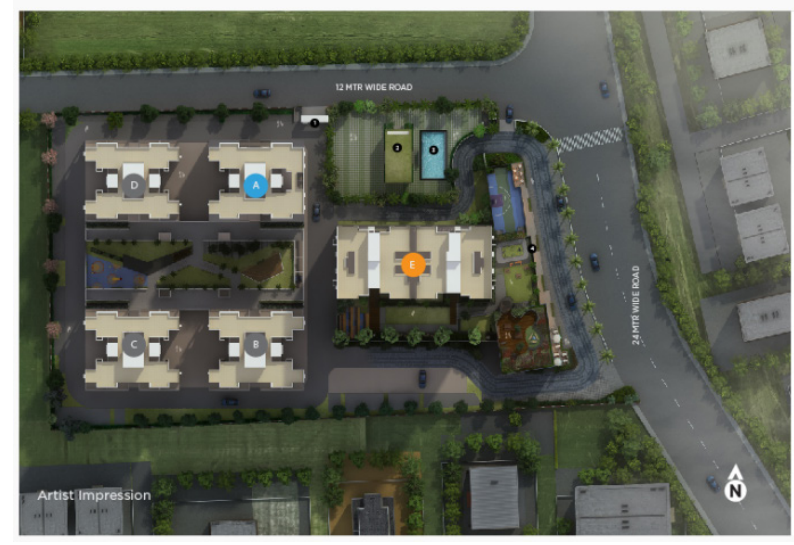

Source:

https://www.javdekars.com/projects/ongoing-projects/palladio-wakad.ht $\mathrm{ml}$

Figure 12. Site Plan

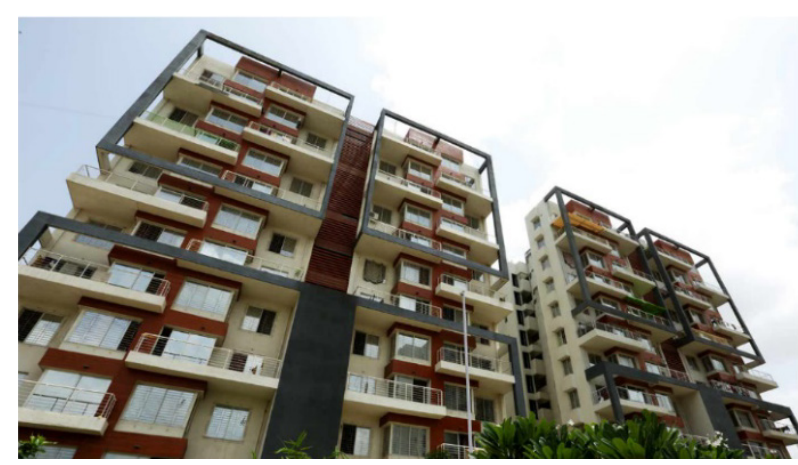

Source: TERI

Figure 13. External face of Palladio, Pune

\subsubsection{Energy Consumption and Daylighting}

The planning of all residential units around the landscape area on the podium layout takes care of daylighting., as shown in Fig 12. Openings were sufficient in size for daylight, and 85 percent of the habitable spaces had proper daylight. [22]

Various techniques such as horizontal shading devices, balconies, and treatment in terraces, appropriate glazing to reduce heat, reduces the direct heat gain by $45 \%$, as shown in Fig 13. Fly ash bricks are used for enveloping and application of heat-reflecting paint on the roof to minimize heat gain. [22]

\subsubsection{Water Conservation}

The installation of the sewage treatment facility on-site for wastewater treatment, and its usage is for landscaping. Native plant species are used for land use to reduce water needs, and a drip irrigation system is used to allow effective use of water for landscaping. There is a reduction of approximately 55.74 percent of water demand for landscaping. [22]

There is a provision of low-flow fixtures, and the use of STP Treated water for flushing through dual flush reduced the building water demand by $25.93 \%$. There is rainwater harvesting provision of recharge pits to collect $100 \%$ runoff from the groundwater recharge roof. [22]

\subsubsection{Sustainable Building Materials}

Fly ash was added in Ordinary Portland cement (OPC) and Rich Mixed Concrete (RMC) to reduce cement and better strength. [22] There is the use of recycled steel and fly ash bricks for building. Fly ash based on PPC and mortar is used, including the use of plaster containing toxic waste. [22] There are aluminum window frames and vitrified tiled having recycled contents, low -VOC paints, adhesives, and sealants are used in construction. [22]

\subsubsection{Case Study 3: Devraai Phase -II, Pune}

The project statistics of Devraai, Pune are shown in Table 19.

Table 19. Project statistics of Devraai Phase-II, Pune

\begin{tabular}{|c|c|}
\hline Occupancy Type & Residential Apartments \\
\hline Built-up area & $3103.48 \mathrm{sqm}$ \\
\hline Site Area & $2125 \mathrm{sqm}$ (0.54 Acres) \\
\hline Completed & 2014 \\
\hline Location & Kiwale, Pune \\
\hline Principal Architect & Sole Space, Pune \\
\hline Green consultant & VK:e environmental LLP \\
\hline Rating System & GRIHA \\
\hline Rating Achieved & 3 Star Final GRIHA Rating \\
\hline
\end{tabular}

Source: GRIHA

\subsubsection{Site Planning}

The site area is very small, still the 51 no native species of tree planted along the periphery of the site to enhance biodiversity as shown in Fig 14. [23] 


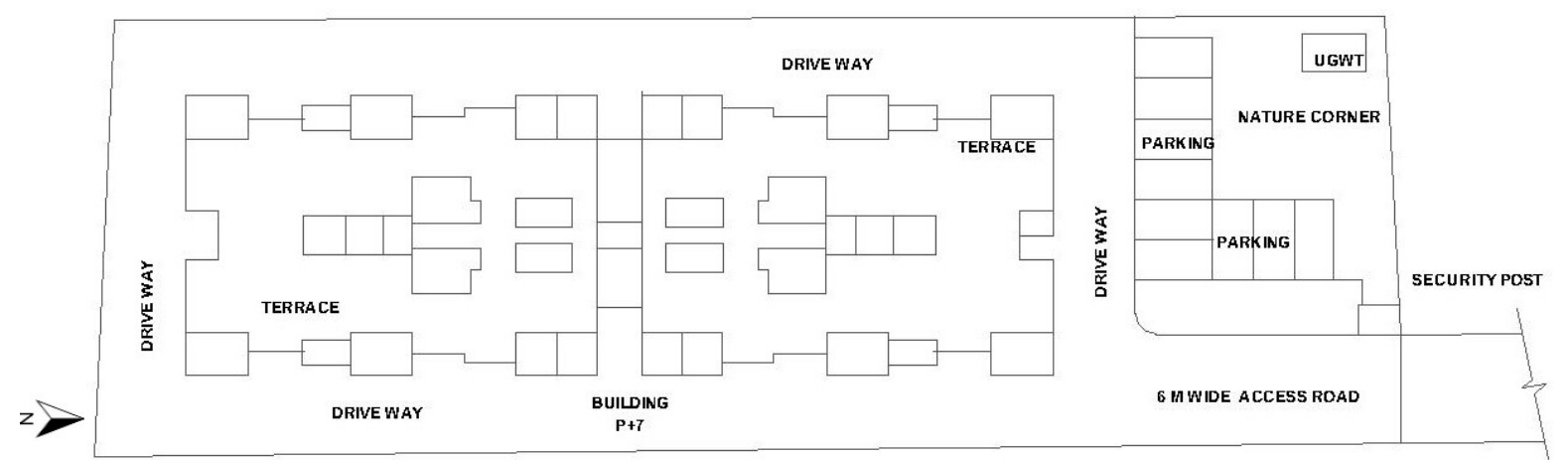

Source: Brochure of Devraai Phase -II by Sanjeevani Developers

Figure 14. Site plan

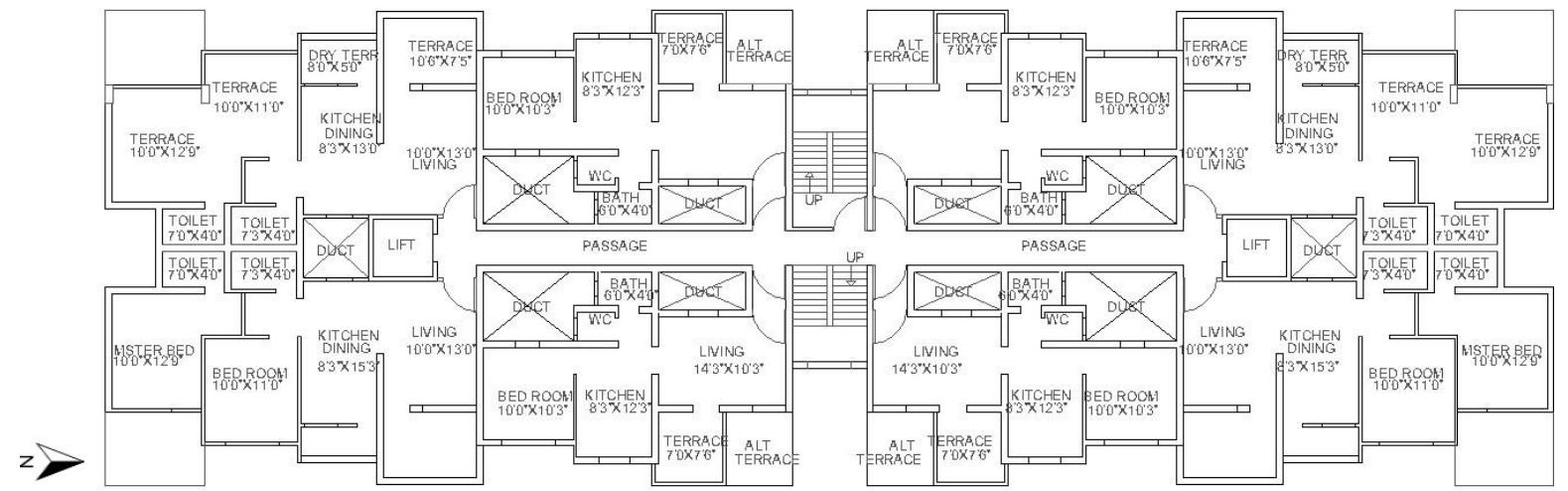

Source: Brochure of Devraai Phase -II by Sanjeevani Developers

Figure 15. Seventh Floor Plan

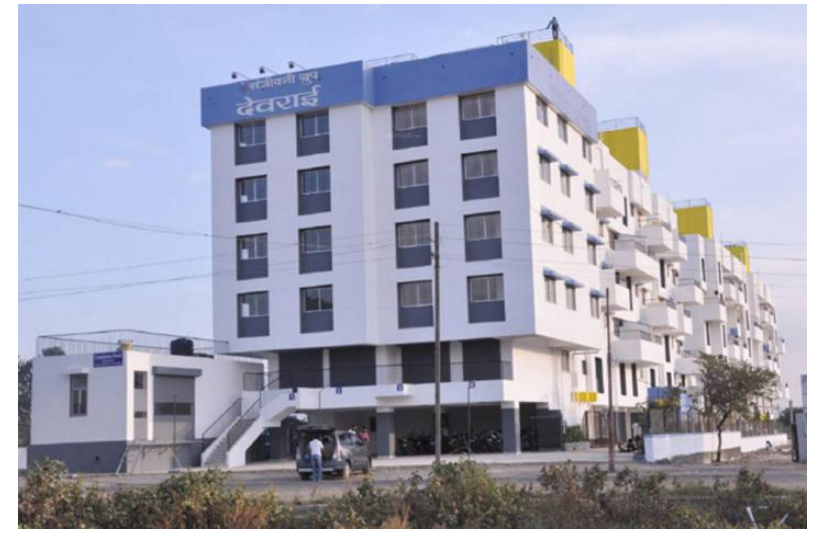

Source: Brochure of Devraai Phase -II by Sanjeevani Developers

Figure 16. View of Devrrai Phase-II

\subsubsection{Energy Consumption and Day Lighting}

The window wall ratio (WWR) was maintained at 14.39 percent for good daylight in the building as a visual connection between the occupant and the outside environment, as shown in Fig 16. Approximately 85 percent of the habitat spaces are well lit and comply with the daylight factors specified by the National Building code of India. [23]

The longer face is facing east and west, as seen in Fig 15, so there are double walls built on the envelope to minimize heat gain, and several energy-efficient steps have taken to reduce the Energy Performance Index (EPI) by 84.5 percent, i.e., $15.5 \mathrm{~kW} / \mathrm{m} 2$ / year compared to the GRIHA benchmark EPI. [23]

A solar hot water system has been installed to offset $96 \%$ of the conventional demand for hot water to reduce conventional energy demand. There is an installation of 3 $\mathrm{kW}$ solar panel capacity to meet the building's common area lighting requirements. [23]

\subsubsection{Sustainable Building Materials}

There were Fly ash bricks with a minimum content of 70.89 percent of ash for 100 percent of the total volume of bricks. Portland Pozzolana Cement (PPC) with a fly ash content of $30 \%$ by weight was used in the plaster and masonry mortar project. [23]

\subsubsection{Water Conservation}

The installation of low-flow plumbing fixtures lowered the demand for building water by 34 percent compared to the GRIHA baseline. The installation of a drip irrigation system saved $75 \%$ of the landscaping water demand. [23]

\section{Conclusion and Recommendations}

The study of the rating system suggests that there are 
similarities and dissimilarities in all three rating systems. The similarity and dissimilarity are seen in the comparative study of the rating system. The creation of Principles of Design is to meet all the criteria of the three rating systems. There are five focus areas for sustainable design principles, namely site planning, energy and daylight use, sustainable building materials, water conservation, and waste management. The other areas are grouped under the miscellaneous heading.

Tzed homes have a Platinum rating, the highest in IGBC ratings, which is the best practice of IGBC in this paper. The Palladio is again not a very large project and has earned a 4-star rating that is one step below the highest rating in GRIHA. Devrrai Phase - II received a 3-star rating despite a minimal project, and there is not much scope for site planning. The three case studies carried out in this paper indicate that there are different parameters for each study due to a variety of factors, such as the designer's approach to achieving a specific rating system and considering sustainable building as a design product, project estimation, project site potential, and other factors. It is not the designer's responsibility since the client wished to achieve a specific rating system, and the designer should meet the requirements of a specific rating system. The designer's role has become minimal, and many Principles of Design for proper Sustainable Housing have been overlooked. The Principles of Design outlined in this paper serve as a ready guideline for designers to implement the maximum Principles of Design to determine the true spirit of sustainable design and obtain the building rating. It is advised that other researchers could further explore the Principles of Design.

\section{Acknowledgments}

The author acknowledges the agencies' support for the study of T-Zed Homes in 2013 to pursue M. Arch Thesis. The author has no commercial interest in any projects under discussion; this is a strictly academic research paper. The authors highlight all organizations' assistance by presenting information relevant to the research paper on their website.

The author acknowledges the support of all faculty members who have guided the path of M.Arch. The author also honors his Ph.D. contribution: Guide Dr. Prabhjot Kaur and Co-Guide Dr. I.P. Singh for their valuable guidance on this research paper.

The author acknowledges the Punjab Technical University's support in providing access to excellent library services and other infrastructure facilities. The author acknowledges the Chandigarh Administration's cooperation in providing the best infrastructure facilities at the Chandigarh College of Architecture and other research support facilities.

\section{REFERENCES}

[1] Richard Rekhy, Navin Raheja. Bridging the Urban Housing Shortage in India [Internet]. KPMG and NAREDCO; $2012 \mathrm{p}$. 20. Available from: http://www.risingstraits.com/images/pd f/Urban-housing-shortage-in-India.pdf

[2] Singh Shanker Vijay, Pandey Narayan Deep. Sustainable Housing: Balancing Environment with Urban Growth in India [Internet]. Jaipur: Climate Change and CDM Cell Rajasthan State Pollution Control Board; 2012. Available from:

https://dlc.dlib.indiana.edu/dlc/bitstream/handle/10535/879 4/Pandey.pdf? sequence $=1$

[3] Golubchikov O, Badyina A. Sustainable housing for sustainable cities. Kenya: United Nations Human Settlements Programme (UN-Habitat); 2012.

[4] Saigaonkar, RishabhG., Pimplikar S. S., Aher. Unique Rating System for Green Building: By Comparing Various Existing Rating Systems. International Journal of Engineering Research and Applications, Vol. 4, Issue 1(Version2), pp.197-206, January 2014.

[5] Kanaujia Virendra, Reddy Arukala Suchith, and Kumar G Kalyan. Comparative Review of Indian Green Building Rating Systems.Journal of Energy Research and Environmental Technology (JERET), Volume 4, Issue 2, pp. 194-198, April-June, 2017.

[6] Pamu Yashwanth, Mahesh Kona. A Comparative Study on Green Building Rating Systems in India in terms of Energy and Water. CVR Journal of Science and Technology, Volume 16, pp 21-25, June 2019. DOI: $10.32377 /$ cvrjst1604.

[7] Joseph Kiran, Jose Victor, Kumar A N Dinesh, Sunny Sithara Mary. A Review on various Green Building Rating Systems in India. International Journal of Scientific \& Engineering Research, Volume 9, Issue 5, pp 1851-1859, May-2018.

[8] Jadhav Laxman, Lokhande Shivani, Bade Apurva, Tupe Anant, Sankpal Aru. International Journal of Engineering Research \& Technology (IJERT) Vol. 8, Issue 12, pp 694-699, December-2019.

[9] Thanu H.P., Rajasekaran C. Comparative study on Indian building assessment tools and its limitations. International Conference on Sustainable Development at Columbia, Srilanka, 2017. Online available fromhttp://multidisciplinar yjournal.globalacademicresearchinstitute.com/images/esd/h pthanu.pdf.

[10] Sande Iliyas Ikbal, Phadtare N. S.Comparative Study of LEED and GRIHA Rating System. Journal of Information, Knowledge, and Research in Civil Engineering. Volume 3, Issue 2,168-174,2015.

[11] Definitions of Sustainability [Internet]. Ecifm.rdg.ac.uk. 2020 [cited 25 October 2020]. Available from: http://www.ecifm.rdg.ac.uk/definitions.htm

[12] James P, Magee L. Domains of Sustainability. Global Encyclopedia of Public Administration, Public Policy, and Governance [Internet]. 2016 [cited 25 October 2020]; 1-17. Available from:https://link.springer.com/referenceworkentr y/10.1007\%2F978-3-319-31816-5_2760-1 
[13] Principles of Sustainable Design [Internet]. Designorate. 2014 [cited 25 October 2020]. Available from: https://www.designorate.com/principles-of-sustainable-desi $\mathrm{gn} /$

[14] Cushman-Roisin B. Sustainable Design Principles. Presentation presented at; 2019; Thayer School of Engineering, Dartmouth. Available from: http://www.dartmouth.edu/ cushman/courses/engs44/Desig nPrinciples.pdf

[15] Confederation of Indian Industries. IGBC Green Residential Societies, Version -1. Hyderabad: Indian Green building Council; 2020 p. 76. Available from: https://igbc.in/igbc/redirectHtml.htm?redVal=showgreenres Societynosign

[16] Green Rating for Integrated Habitat Assessment (GRIHA) Council of India. GRIHA for affordable Housing, Abridged Manual. New Delhi: TERI Press, The Energy and Resource Institute; 2017 p. 94. Available from: https://www.grihaindia.org/manuals

[17] Department of Science and Technology, Govt. of India. Eco Housing Assessment Criteria's Version -II. Mumbai: International Institute for Energy Conservation; 2009 p. 78 Available from: https://www.ecohousing.in/Criteria.php
[18] Sustainable Spaces. Architecture + Design, Nov 2008.

[19] Développement, A., 2020. Case Study III: TZED Homes In Bangalore By BCIL - Architecture Et Développement. [online] Architecture et Développement. Available at: $<$ https://www.archidev.org/spip.php?article1151> [Accessed 25 October 2020].

[20] Tropical Buildings [Internet]. Tropicalbuildings.org. 2020 [cited 25 October 2020]. Available from: https://www.tropi calbuildings.org/case_studies/91

[21] Waste Management for Apartments - Slides - ADDA BLOG [Internet]. ADDA BLOG. 2012 [cited 25 October 2020]. Available from: https://adda.io/blog/2012/10/waste-manage ment-for-apartments-slides/

[22] Case Studies: Palladio, Pune [Internet]. Grihaindia.org. 2020 [cited 25 October 2020]. Available from: https://www.grihaindia.org/sites/default/files/sites/default/fi les/pdf/case-studies/Palladio_new-GRIHA-case-study-card. pdf

[23] Case Studies: Devraai Phase -II [Internet]. Grihaindia.org. 2020 [cited 25 October 2020]. Available from: https://www.grihaindia.org/sites/default/files/sites/default/fi les/pdf/case-studies/Devraai-Phase-2.pdf 